\title{
PELATIHAN PEMANFAATAN TEKNOLOGI INFORMASI UNTUK PENGELOLAAN DATA LAZISMU SE-DIY
}

\author{
Oleh: Jefree Fahana, Supriyanto \\ Universitas Ahmad Dahlan Yogyakarta
}

\section{Ringkasan}

LAZISMU PWM D.I. Yogyakarta dalam melakukan pengelolaannya dibantu oleh 5 (lima) LAZIS tingkat Daerah Kota/Kabupaten, baik dalam hal penghimpunan maupun pentasyarufan dana ZIS serta pendataan donator maupun muzaki dan lainnya. Namun dalam pengelolaan data tersebut tidak ada integrasi dan sinkronisasi sehingga data-data yang ada di daerah-daerah tidak dimiliki oleh wilayah. Imbasnya adalah laporan yang dimiliki wilayah sangatlah sedikit dan tidak berkorelasi dengan data-data dilapangan yang dihimpun oleh daerah-daerah. Berkait dengan kondisi tersebut, maka dilaksanakan pelatihan pemanfaatan teknologi informasi untuk pengelolaan data LAZISMU PWM D.I. Yogyakarta. Harapannya dengan pelatihan ini para pengelolaan LAZISMU Daerah dan Wilayah memiliki keahlian untuk melakukan sinkronisasi dan komunikasi pada seluruh jajaran LAZISMU se-DIY ataupun dengan para donator maupun Muzaki. Materi pelatihan yang diberikan adalah teknologi-teknologi milik Google atau biasa disebut dengan Google Apps. Aplikasi Google yang digunakan meliputi: Google Mail, Google Drive, Google Docs, Google Calendar. Materimateri tersebut disampaikan dengan metode pelatihan yang berisi ceramah, penyampaian modul kegiatan, pemberian contoh kasus dan simulasi serta evaluasi atau pendampingan pemanfaatan teknologi informasi Google Apps Pelatihan dilaksanakan selama empat hari. Setiap harinya peserta pelaatihan mendapatkan materi yang berbeda mulai dari Google Email sampai dengan Google Calendar. Peserta yang hadir dating dari perwakilan pengelola LAZISMU Cabang maupun LAZISMU Daerah. Setelah mengikuti pelatihan ini, peserta dapat melkukan pengelolaan data LAZISMU dengan baik dan terintegrasi dengan LAZISMU Wilayah. Pelatihan tentang teknologi informasi yang telah diberikan dapat meningkatkan kemampuan pengelola LAZISMU baik tingkat Cabang, Daerah, maupun Wilayah. Akan tetapi kemampuan ini juga harus didukung oleh prosedur atau sistem pengelolaan yang baik. Sehingga penggunaan teknologi informasi dan integrase dapat berjalan dengan baik.

Kata kunci: Pemanfaatan Teknologi, Lazismu, Teknologi Informasi, Pengelolaan Data

\begin{abstract}
LAZISMU PWM D.I. Yogyakarta in carrying out its management is assisted by 5 (five) LAZIS level of Town Region both in terms of collection and pentasyarufan ZIS funds and data collection of donators and muzaki and others. But in the management of the data there is no integration and synchronization so that the data that exist in these areas is not correlated with field data collected by the regions. Associated with these conditions, then implemented training on utilization of information technology for data management LAZISMU PWM D.I. Yogyakarta. Hopefully with this training the managers of LAZISMU Region and Territory have the expertise to synchronize and communicate to all LAZISMU members in DIY or with donors and Muzaki. The training materials provided are technologies owned by Google or commonly referred to as Google Apps. The Google apps used include: Google Mail, Google Drive, Google Docs, Google Calendar. The materials are delivered with a training method that contains lectures, delivery of activity modules, case samples and simulations as well as evaluation or mentoring of the utilization of Google Apps information technology Training was conducted over four days. Every day participants pelatenihan get different materials ranging from Google Email sampai dengan Google Calendar. Participants are present from the representatives of LAZISMU Branch and LAZISMU Daerah. After participating in this training, participants will be able to manage the LAZISMU data well and integrate with LAZISMU Territory. Training on information technology that has been given to improve the ability of
\end{abstract}


LAZISMU managers both Branch, Region, and Region levels. However, this ability must also be supported by good management procedures or systems. So the use of information technology and integrase can work well.

Keywords: Technology Utilization, Lazismu, Information Technology, Data Management

\section{PENDAHULUAN}

LAZISMU PWM D.I. Yogyakarta merupakan lembaga zakat nasional. Berdasarkan hasil musyawarah wilayah Muhammadiyah D.I. Yogyakarta di Gunungkidul pada tahun 2015, bahwa pengelolaan Lazis harus dilakukan secara professional dan transparan serta akuntabel sehingga mampu meningkatkan kepercayaan masyarakat terhadap kelembagaan Lazis.

Meningkatnya kepercayaan kelembagaan akan berimbas pada semakin banyaknya donator maupun muzaki dalam mendonasikan hartanya kepada lazis. Selain itu, akan meningkatkan peran lazis dalam upaya untuk melakukan pemberdayaan masyarakat dalam hal ini khususnya adalah masyarakat yang termasuk dalam 8 (delapan) asnaf penerima dana ZIS.

LAZISMU PWM D.I. Yogyakarta dalam melakukan pengelolaannya dibantu oleh 5 (lima) LAZIS tingkat Daerah Kota/Kabupaten, baik dalam hal penghimpunan maupun pentasyarufan dana ZIS serta pendataan donator maupun muzaki dan lainnya. Namun dalam pengelolaan data tersebut tidak ada integrasi dan sinkronisasi sehingga data-data yang ada di daerah-daerah tidak dimiliki oleh wilayah. Imbasnya adalah laporan yang dimiliki wilayah sangatlah sedikit dan tidak berkorelasi dengan data-data dilapangan yang dihimpun oleh daerah-daerah.

Berkait dengan kondisi tersebut, maka dilaksanakan pelatihan pemanfaatan teknologi informasi untuk pengelolaan data LAZISMU PWM D.I. Yogyakarta. Kegiatan ini bertujuan memberikan pemahaman dan kecakapan kepada pengelola Lazismu Muhammadiyah DIY dalam pengelolaan data yang berbasis Teknologi Informasi. Harapannya para pengelola LAZISMU Daerah dan Wilayah memiliki keahlian untuk melakukan sinkronisasi dan komunikasi pada seluruh jajaran LAZISMU se-DIY ataupun dengan para donator maupun Muzaki.

Teknologi Informasi (TI), atau dalam bahasa Inggris dikenal dengan istilah Information technology (IT) adalah istilah umum untuk teknologi apa pun yang membantu manusia dalam membuat, mengubah, menyimpan, mengomunikasikan dan/atau menyebarkan informasi. TI menyatukan komputasi dan komunikasi berkecepatan tinggi untuk data, suara, dan video.

Pengolahan, penyimpanan dan penyebaran vokal, informasi bergambar, teks dan numerik oleh mikroelektronika berbasis kombinasi komputasi dan telekomunikasi. Istilah dalam pengertian modern pertama kali muncul dalam sebuah artikel 1958 yang diterbitkan dalam Harvard Business Review, di mana penulis Leavitt dan Whisler berkomentar bahwa "teknologi baru belum memiliki nama tunggal yang didirikan. Kita akan menyebutnya teknologi informasi (TI). ". Beberapa bidang modern dan muncul teknologi informasi adalah generasi berikutnya teknologi web, bioinformatika, "Cloud Computing", sistem informasi global, Skala besar basis pengetahuan dan lain-lain. 
Diterbitkan oleh Lembaga Pengabdian kepada Masyarakat

Universitas Ahmad Dahlan Yogyakarta

Google menyediakan aplikasi yang dapat dimanfaatkan untuk mengolah data dan informasi baik untuk bidang pendidikan, perkantoran, bisnis, bahkan keperluan pribadi. Beberapa aplikasi yang ditawarkan adalah aplikasi surat elektronik yaitu Google Mail, aplikasi penyimpanan berbasis Cloud yaitu Google Drive, aplikasi pengolah dokumen yaitu Google Docs, dan aplikasi pengelola kalender yaitu Google Calendar. Versi gratis dari beberapa aplikasi sangat cukup untuk mengelola data dan informasi perkantoran maupun sekolah. Tetapi untuk mendapatkan pelayanan lebih seperti kapasitas penyimpanan yang lebih besar bahkan tak terhingga perlu menggunakan versi berbayar dari aplikasi Google tersebut.

\section{A. METODE PELAKSANAAN}

Materi pelatihan yang diberikan adalah teknologi-teknologi miik Google atau biasa disebut dengan Google Apps. Aplikasi Google yang digunakan meliputi: Google Mail, Google Drive, Google Docs, Google Calendar. Materi dikemas sedemikian rupa dalam modul pelatihan.

1. Ceramah, diberikan pengantar dan arahan agar peserta memahami gambaran pelatihan dan targer capaian.

2. Pemberian modul kepada peserta, sehingga peserta lebih mudah dalam menerima dan memahai materi yang diberikan, sehingga kegiatan ini lebih efektif; serta pemberian contoh dan kasus permasalahan, sehingga diharapkan peserta akan lebih memahami cara menggunakan aplikasi Google untuk pengelolaan data dan informasi;

3. Evaluasi, Dilakukan evaluasi hasil pemanfaatan aplikasi google untuk pengelolaan data LAZISMU DIY.

\section{B. HASIL, PEMBAHASAN DAN DAMPAK}

Kegiatan pelatihan bertempat di Gedung PWM D.I. Yogyakarta. Sasaran peserta adalah pengelola LAZISMU dari tingkat Cabang, Daerah maupun Wilayah D.I.Yogyakarta. Perwakilan yang hadir terdiri dari Daerah Kota Yogyakarta, Kabupaten Gunungkidul dan Kabupaten Bantul.

Kegiatan pelaksanaan pelatihan diuraikan dalam Tabel 1 berikut:

Tabel 1. Uraian kegiatan pelatihan

\begin{tabular}{|l|l|l|}
\hline Kegiatan & Uraian Kegiatan & Output Kegiatan \\
\hline $\begin{array}{l}\text { Pelatihan } \\
\text { hari ke-1 }\end{array}$ & $\begin{array}{l}\text { Melaksanakan kegiatan pelatihan } \\
\text { pemanfaatan teknologi dengan } \\
\text { materi Google Mail dan penugasan }\end{array}$ & $\begin{array}{l}\text { 1. Kegiatan pelatihan } \\
\text { 2. Peserta mengerjakan tugas } \\
\text { menyeragamkan format penamaan } \\
\text { email untuk pengelola LAZISMU. }\end{array}$ \\
\hline $\begin{array}{l}\text { Pelatihan } \\
\text { hari ke-2 }\end{array}$ & $\begin{array}{l}\text { Melaksanakan kegiatan pelatihan } \\
\text { pemanfaatan teknologi dengan } \\
\text { materi Google Drive dan } \\
\text { penugasan }\end{array}$ & $\begin{array}{l}\text { 1. Kegiatan pelatihan } \\
\text { Peserta mengerjakan tugas simulasi }\end{array}$ \\
\end{tabular}




\begin{tabular}{|l|l|l|} 
& & $\begin{array}{l}\text { data dengan memanfaatkan Google } \\
\text { Drive }\end{array}$ \\
\hline $\begin{array}{l}\text { Pelatihan } \\
\text { hari ke-3 }\end{array}$ & $\begin{array}{l}\text { Melaksanakan kegiatan pelatihan } \\
\text { pemanfaatan teknologi dengan } \\
\text { materi Google Docs dan penugasan }\end{array}$ & $\begin{array}{l}\text { 1. Kegiatan pelatihan } \\
\text { 2. Peserta mengerjakan tugas membuat }\end{array}$ \\
& $\begin{array}{l}\text { dokumen-dokumen menggunakan } \\
\text { Google Docs dan melakukan simulasi } \\
\text { membuat laporan dengan cara } \\
\text { kolaborasi. }\end{array}$ \\
\hline $\begin{array}{l}\text { Pelatihan } \\
\text { hari ke-4 }\end{array}$ & $\begin{array}{l}\text { Melaksanakan kegiatan pelatihan } \\
\text { pemanfaatan teknologi dengan } \\
\text { materi Google Calendar dan }\end{array}$ & $\begin{array}{l}\text { Kegiatan pelatihan } \\
\text { 2. Peserta membuat simulasi membuat }\end{array}$ \\
& $\begin{array}{l}\text { penugasan } \\
\text { acara dan mengundang peserta lain }\end{array}$ \\
\hline $\begin{array}{l}\text { Pendamping } \\
\text { an kegiatan } \\
\text { pengelolaan } \\
\text { data }\end{array}$ & $\begin{array}{l}\text { Melakukan pendampingan kepada } \\
\text { peserta yang telah mengikuti } \\
\text { pelatihan dengan cara } \\
\text { daring/online. }\end{array}$ & $\begin{array}{l}\text { Pembuatan Google Group dan kolaborasi } \\
\text { Google Drive yang beranggotakan peserta } \\
\text { pelatihan dan pengelola LAZISMU PWM } \\
\text { DIY. }\end{array}$ \\
\hline
\end{tabular}

Dampak yang dirasakan saat dan setelah pelatihan adalah peserta antusias mengikuti pelatihan dan antusias untuk segera menerapkan teknologi informasi dalam proses pengelolaan data ZIS yang selama ini terkendala.

\section{KESIMPULAN}

Penerapan teknologi google App. Pada lazismu dapat diterapkan dengan baik meskipun masih ada sedikit kendala dalam hal prosedur pengelolaan data di internal lazismu. Sehingga, Perlu adanya prosedur pengelolaan yang memadai sehingga dalam penerapan teknologi ini dapat secara optimal. Selain itu, perlu diadakan kegiatan pelatihan yang sama di Lazismu Daerah yang melibatkan Lazismu tingkat Cabang ataupun Pimpinan Cabang Muhammadiyah sehingga data rekapitulasi ZIS se-DIY dapat tersinkronisasi.

Apabila semua pengella LAZISMU sudah mendapatkan pelatihan dan telah menerapkan teknologi informasi dalam mengelola data ZIS, maka sebagai tindak lanjut perlu dibangun sistem informasi yang khusus untuk mengelola data ZIS.

\section{DAFTAR PUSTAKA}

Williams \& Sawyer, Using Information Technology 11th Edition McGraw Hill, 2014. Longley, Dennis \& Shain, Michael, Dictionary of Information Technology 2nd Edition, Macmillan Press, 1985.

Wikipedia, Teknologi informasi, https://id.wikipedia.org/wiki/Teknologi_informasi, diakses tanggal 1 November 2016. 